Copyright (C) 2014 by Academic Publishing House Researcher

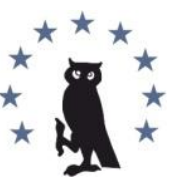

Published in the Russian Federation

European Researcher

Has been issued since 2010.

ISSN 2219-8229

E-ISSN 2224-0136

Vol. 84, No. 10-1, pp. 1789-1794, 2014

DOI: $10.13187 / \mathrm{er} .2014 .84 .1789$

www.erjournal.ru



UDC 304

\title{
Present-Day Trends in the Development of Russian Education and the Mentality of the Russian Nation
}

\author{
${ }^{1}$ Anna V. Vinevskaya \\ ${ }^{2}$ Oyuna B. Ochirova
}

\author{
${ }^{1}$ Taganrog Institute of Chekhov (branch) "RGEU (RINH)", Russian Federation \\ $\mathrm{PhD}$, Associate Professor \\ E-mail: annkurepina@rambler.ru \\ ${ }_{2}^{2}$ St. Petersburg State University, Russian Federation \\ University Emb. 7-9, St. Petersburg, 199034 \\ the applicant \\ E-mail: oyuna170@gmail.com
}

\begin{abstract}
This article aims to illustrate the need to consider adopting new trends in Russian education through the prism of the mentality of Russian society. To provide a rationale for the author's position, the work employs the axiological and milieu approaches. The article demonstrates that one should take account of the nation's mentality in order to introduce innovations in a proper way. The work provides a rationale for the author's position concerning the perception of the nation's mentality through the prism of systemic-vector psychology developed by Yuri Burlan.

Keywords: mentality; education; Russian mentality; Yuri Burlan's systemic-vector psychology.

\section{Введение}

В современном образовании все чаще встречаются ситуации, когда не работающие или работающие с трудом технологии заставляют задуматься о том, насколько правильно и корректно выбран курс реформирования образования. Так, всем известна плохо работающая технология ЕГЭ, которую Министерство образования и науки РФ вынуждено адаптировать к реалиям России; уже не первый год; вызывает споры и непонимание среди педагогов навязывание технологии дистанционного обучения; однобоко, «с нажимом» внедряются технологии электронного обучения. Там, откуда пришли к нам эти технологии, они в целом работают и дают устойчивый стабильный результат, а сам процесс технологизации образования - это общая тенденция, которая давно признана мировым сообществом.

Кроме того, необходимо акцентировать внимание и на ценностях и тенденциях в образовании, которые были предложены Болонским соглашением, а именно - это мобильность, студентоцентрированный подход, компетенции и конкурентоспособность [1].

Те задачи, которые поставлены педагогической общественности Министерством образования и науки РФ, не идут в разрез с мировыми тенденциями в образовании, однако,
\end{abstract}


как уже было сказано выше, вызывают много вопросов как у административных работников, так и у педагогов и родителей. Налицо противоречия между современными мировыми тенденциями в образовании и сложившейся ситуацией в образовательной теории и практике России; между «проталкиванием» новых ценностей в системе образования и готовностью эти ценности принять у общественности. Вышеназванные противоречия ставят перед нами проблему, которая вытекает из указанных противоречий и отвечает на вопрос: понимание каких процессов и общественных явлений будет способствовать тому, что преобразования в российском образовании приживутся и будут оптимальными?

\section{Материалы и методы}

В статье использована как периодическая, так и монографическая литература ведущих ученых.

Целый ряд исследовательских и научных работ были посвящены разрешению вопроса возможности использования технологий, которые дают эффективный результат и используются в дальнейшем в одной социальной структуре и невозможность перенесения хорошего опыта в другие структуры. Авторы настоящей статьи решили рассмотреть эту проблему несколько под иным углом зрения. Для рассмотрения указанной проблемы мы применили аксиологический и средовой подходы.

Аксиологический подход подразумевает рассмотрение вопросов под углом ценностного компонента, смыслового содержания и наполнения. Именно в образовательной сфере необходимо уделять пристальное внимание ценностной проблематике, пониманию роли ценностей как базиса, основы личности, «движущей силы» в воспитании и развитии лучших качеств; именно ценности дают движение в верном стратегическом направлении, которое задаётся образом культурного идеала, «идеальным должным» [2].

Средовой подход представляет собой теорию осуществляемого через проектируемую среду управление процессом формирования и развития человека. Среда выступает как средство комплексного целенаправленного воздействия на личность, формируя личность по своему образу и подобию, раскрывая разнообразные возможности для развития личности [3].

Таким образом, чтобы ответить на поставленные вопросы, необходимо детально рассмотреть прежде всего ту среду, в которую должны быть внесены преобразования, изучить систему ценностей, которая является устоявшейся в данной среде.

\section{Обсуждение}

Как соотносятся между собой новые тенденции в образовании и особенности российской ментальности? Можем ли мы сказать, что ментальность и образование связаны?

Обратимся к ключевым понятиям. Менталитет современными исследователями, например, Б.И. Коненко, понимается в общем смысле как «...те духовно-нравственные и культурные ценности, которые составляют основу мировидения и миропонимания отдельного человека или сообщества, в свою очередь, определяющих их поведение» [4]. Менталитет определяют глубинный духовный склад личности или нации, как образ чувств и мыслей, определяющих действия и поступки его носителей. И надо заметить в этой связи, что менталитет складывается веками, тысячелетиями и проявляет себя в историкогенетической памяти народа. Только зная определенные особенности менталитета народа или общности людей можно понять, почему в сходных ситуациях разные народы (и люди) ведут себя по-разному. Менталитет формируется под влиянием различных факторов - это влияние и среды существования, и геоклиматических условий, и культурных особенностей и традиций. Каждый отдельно взятый человек, являясь носителем определенного менталитета, проживая свою жизнь, оценивает поступки и чувства других людей через призму присущей ему ментальности. И конечно, без знания менталитета целого народа или отдельно взятого человека, нельзя выстроить успешное взаимодействие, т.е. такое взаимодействие, которое бы не создавало конфликты и социальные катастрофы. Таким образом, особенности того, как будет происходить восприятие и оценка окружающего мира человеком или общностью людей, будет зависеть прежде всего от того, носителями какого менталитета они являются. А то общее, имеющее надситуативный характер, что лежит в основе коллективного бессознательного определенной социальной общности, что 
заложено глубинно и проявляется как в обыденной жизни, так и в результатах жизнедеятельности всего социума, и будет определяться как менталитет народа или нации.

Что об этом говорят современные исследователи? Что же такое русский, а вернее, российский менталитет? Как определяют отечественные исследователи Л.Н. Гумилев, И.А. Ильин, В.О. Ключевский и др. особенности и отличия российского (русского) менталитета? Приведем высказывание известного русского философа И.А. Ильина о русской душе: «Русская культура, прежде всего, построена на чувстве и сердце, на созерцании, на свободе совести и свободе молитвы. Это они являются первичными силами и установками русской души, которая задает тон их могучему темпераменту... русский народ народ сердца и совести. Здесь источник его достоинств и недостатков. В противоположность западному человеку здесь все основано на свободной доброте и на несколько мечтательном, порою сердечном созерцании. Отсюда и терпение, почти "божественная крепость" русского человека, простота и достоинство, "удивительно спокойное отношение к смерти" как предельной форме зла» [5, С. 146]. Почему сформировались столь особенные и непонятные, например, для европейцев, качества у целого народа?

Как само Российское государство, так и российский этнос были географически, исторически, социально и психологически «слеплены» в результате мощного воздействия природных сил, других параллельно развивающихся цивилизаций. Наша ментальность это результат адаптации народа к тем суровым условиям выживания, которые были связаны с проживанием на больших открытых территориях, противостоянием суровому холодному климату, приспособлением к скудным урожаям, когда основная цель социальной общности - выжить во что бы ни стало. Именно поэтому выживание было обеспечено совместным трудом, коллективным ведением хозяйства, взаимопомощью, взаимовыручкой, общинностью, культивированием принадлежности и единства «с миром».

Опять же, И.А. Ильин писал: «Россия поставила нас лицом к лицу с природой, суровой и захватывающей, с холодной зимой и раскаленным летом, с безнадежной осенью и бурною, страстною весною. Она погрузила нас в эти колебания, заставила нас жить их властью и глубиной. Именно столь противоречив русский характер» [5, С. 167].

Так, замечаются в русских людях такие качества, как противоречивость, жажда абсолютной свободы, покорность, гостеприимство, терпение, религиозность и атеизм, способность к напряженному труду на короткое время, а также «великорусский авось» (по В.О. Ключевскому). Именно поэтому тип нашей национальной ментальности не понимаем ни Европой, ни Америкой.

В.О. Ключевский раскрывает ландшафтную предопределяемость русского характера так: «Великороссия XIII-XV вв. со своими лесами, топкими болотами на каждом шагу представляла поселенцу тысячи мелких опасностей, затруднений и неприятностей, среди которых надо было найтись, с которыми приходилось поминутно бороться. Это приучало великоросса зорко следить за природой, смотреть в оба, по его выражению, ходить, оглядываясь и ощупывая почву, не соваться в воду, не поискав броду, развивало в нем изворотливость в мелких затруднениях и опасностях, привычку к терпеливой борьбе с невзгодами и лишениями» [6].

Замечательно то, что и современные исследования российской ментальности не только опираются на описательный характер исторических работ великих русских исследователей, но и рефлексивно отслеживают особенности менталитета, объясняя, на первый взгляд необъяснимые вещи, которые в XIX-XX вв. могли возникнуть только в нарративном ключе.

B XXI веке в рамках нового направления в науках о Человеке - системно-векторной психологии Ю.Бурлана, впервые дается определение российского менталитета как уретрально-мышечного менталитета. В системно-векторной психологии есть понятие «уретральная мера», т.е. мера абсолютной отдачи и наполнения себя в этой отдаче. Только вождь, носитель уретрального вектора, способен к полной отдаче и удовлетворению всех потребностей членов его группы. Через эту отдачу он реализует свою видовую роль - каждому по потребности для движения вперед, для развития, для сохранения группы в целостности. Достижение же полной реализации себя, определяемого уретральной мерой, возможно только в случае насыщения и наполнения окружающих по его нехваткам, «...расширение своего присутствия территориально, широкий неограниченный простор - место для приложения энергии. Суть уретрального 
вектора - отдача от себя всем, на всеобщее благо, неограниченно и вдоволь. Уретральный человек не терпит ограничений, он их просто не видит, не замечает, в любой момент готов уйти «за флажки», для него не существует правил» [7].

Русский народ всегда был общинным народом. Соборность русских - одно из ключевых явлений, которое объясняет особое качество взаимодействия людей и наш менталитет. Жизнь среди необъятных степей, бесконечных лесов и равнин, шири и простора полей в непростых климатических условиях не отталкивала людей друг от друга, не разобщала, а объединяла. Так веками складывался менталитет большой объединенной общности людей, которая выживала сообща в «свободном духовном единении» [8], как в мирской, так и в духовной жизни. Смысл жизни и счастье для нас, русских, определяемое нашим менталитетом, обозначает принадлежность, ощущение себя частью чего-то большого. Эта часть - это связь, как духовная, так и физическая, ощущение себя в гуще событий, принадлежность к общности людей, объединенных чем-то незримым единым, ощущение себя действенной и защищенной частью этой общности. Именно наш российский менталитет - уретрально-мышечный менталитет, т.е. наш общий глубинный духовный склад позволяет почувствовать принадлежность к единому целому - народу, с которым связан незримыми духовными нитями [9].

Менталитет по природе своей консервативен. Человеческое мышление, формируемое в значительной степени менталитетом, не может перестроиться быстро. Менталитет, как совокупный психический склад исторической общности людей и образование, как социальный институт, находятся в сложном взаимодействии. Качество и состояние образования и менталитет нации - величины взаимосвязанные и взаимозависимые. И в то же время именно образование, как социальный институт, обеспечивающий передачу знаний, традиций, ценностей социальной общности воссоздает, укрепляет, продолжает во времени существование определенного менталитета.

Каков должен быть ответ на часто возникающие вопросы как у профессионалов, так и у неспециалистов относительно европейских ценностей, которые внедряются в отечественную систему образования? Любые образовательные новации только тогда будут устойчивы и жизнеспособны, если они соответствуют менталитету нации и вводятся на позитивном фоне социального развития. Современное состояние российского социума характеризуется тем, что «прививка» индивидуалистических ценностей западной цивилизации произошла искаженно, поверхностно, из-за архаического состояния определенного пласта общества, определяемого архетипичным «кожным вектором», по системно-векторной терминологии, и не могла произойти по-другому на пространствах заданных вмещающих ландшафтов. Вместо стандартизированного законотворчества и цивилизованного бизнес-подхода, в массе своей получили архетипический разгул коррупции, кумовства и подлога [10].

Система ЕГЭ, например, как система стандартизированного усредняющего тестирования, внедрялась без учета особенностей российской ментальности. И как следствие, мы получили снижение проходных баллов, ЕГЭ-туризм, стяжательство, рост коррупции, приспособление к любым административным мерам воздействия, утечки информации о содержании тестирования. Трудно за короткий временной срок изменить менталитет, еще труднее навязать ментально однородному обществу чуждые нововведения, тем более на таком этапе, когда определенный слой общества характеризуется архетипическими ценностями.

\section{Заключение}

Менталитет русского народа устойчив и особенность россиян в том, что они способны сплотиться в трудные времена. Возможно, что настало это время для нашего отечественного образования. Ведь только системное осознание глубинных особенностей менталитета, культурных традиций и понимание современного состояния социума поможет пересмотреть те хаотичные попытки реформирования российского образования. Не всякое навязываемое, вслепую скопированное новшество является инновацией. Вновь выстраиваемая система должна не разрушать, а учитывать особенности индивидуального и общественного сознания людей, их жизненных позиций, культуры, моделей поведения, обусловленных социальной средой, национальными традициями, т.е. менталитетом. 


\section{Примечания:}

1. Виневская А.В. К проблеме профессиональной мобильности педагога. //Инновации в образовании. 2012. №8. С. 49-59.

2. Видгоф В.М. Онтология междисциплинарного подхода и гуманистический принцип эстетико-ориентированной педагогики. Вестник Томского государственного университета. Философия. Социология. Политология. 2008. № 3. С. 61-64.

3. Мануйлов Ю.С. Средовой подход в воспитании. М. - Нижний Новгород, 2002. C. 126.

4. Кононенко Б.И. Большой толковый словарь по культурологии. М.: Изд-во: Вече 2000, АCT, 2003.

5. Ильин И.А. Сущность и своеобразие русской культуры. М., 1992.

6. Ключевский В.О. Курс русской истории. Ч. I // Сочинения: В 8 т. М., 1956. Т.I. C. 294-295.

7. Маточинская А. Загадочная русская душа. [электронный ресурс] Режим доступа. URL: http://www.yburlan.ru/biblioteka/zagadochnaya-russkaya-dusha

8. Хомяков А.С. Полное собрание сочинений. Т.1. Изв-во: Университетская типография. М., 1886-1906.

9. Очирова В.Б. Инновации в психологии: восьмимерная проекция принципа наслаждения // Сборник материалов I Международной научно-практической конференции «Новое слово в науке и практике: Гипотезы и апробации результатов исследований»/ под ред. С.С. Чернова; Новосибирск, 2012. С. 97-102.

10. Очирова В.Б. Системно о толерантности. Взгляд через призму культуры и цивилизации // Методическое пособие по проведению семинаров и игротренингов, направленных на формирование толерантного сознания. / под ред. А.С. Кравцовой, Н.В. Емельяновой; СПб., 2012. С. 109-114.

\section{References:}

1. Vinevskaya A.V. K probleme professional'noi mobil'nosti pedagoga. //Innovatsii v obrazovanii. 2012. №8. S. 49-59.

2. Vidgof V.M. Ontologiya mezhdistsiplinarnogo podkhoda i gumanisticheskii printsip estetiko-orientirovannoi pedagogiki. Vestnik Tomskogo gosudarstvennogo universiteta. Filosofiya. Sotsiologiya. Politologiya. 2008. № 3. S. 61-64

3. Manuilov Yu.S. Sredovoi podkhod v vospitanii. M. - Nizhnii Novgorod, 2002. S. 126.

4. Kononenko B.I. Bol'shoi tolkovyi slovar' po kul'turologii. M.: Izd-vo: Veche 2000, AST, 2003.

5. Il'in I.A. Sushchnost' i svoeobrazie russkoi kul'tury. M., 1992. 295.

6. Klyuchevskii V.O. Kurs russkoi istorii. Ch. I // Sochineniya: V 8 t. M., 1956. T.I. S. 294-

7. Matochinskaya A. Zagadochnaya russkaya dusha. [elektronnyi resurs]- Rezhim dostupa. - URL: http://www.yburlan.ru/biblioteka/zagadochnaya-russkaya-dusha

8. Khomyakov A.S. Polnoe sobranie sochinenii. T.1. Izv-vo: Universitetskaya tipografiya. M., 1886-1906.

9. Ochirova V.B. Innovatsii $\mathrm{v}$ psikhologii: vos'mimernaya proektsiya printsipa naslazhdeniya // Sbornik materialov I Mezhdunarodnoi nauchno-prakticheskoi konferentsii «Novoe slovo v nauke i praktike: Gipotezy i aprobatsii rezul'tatov issledovanii»/ pod red. S.S. Chernova; Novosibirsk, 2012. S. 97-102.

10. Ochirova V.B. Sistemno o tolerantnosti. Vzglyad cherez prizmu kul'tury i tsivilizatsii // Metodicheskoe posobie po provedeniyu seminarov i igrotreningov, napravlennykh na formirovanie tolerantnogo soznaniya. / pod red. A.S. Kravtsovoi, N.V. Emel'yanovoi; SPb., 2012. S. 109-114. 
УДК 304

\section{Современные тенденции развития отечественного образовании и менталитет российской нации}

${ }^{1}$ Анна Вячеславовна Виневская

2 Валентина Батуевна Очирова

${ }^{1}$ Таганрогский институт имени А.П.Чехова (филиал) «РГЭУ (РИНХ)», Российская

Федерация

канд. пед. наук, доцент

E-mail: annkurepina@rambler.ru

${ }^{2}$ Санкт-Петербургский государственный университет, Российская Федерация

Университетская набережная, д. 7-9

соискатель

E-mail: oyuna170@gmail.com

Аннотация. Цель данной статьи - показать необходимость рассмотрения внедрения новых тенденций в российское образование через призму менталитета социальной общности. Для обоснования авторской позиции был использован аксиологический и средовой подходы. В статье показано, что необходимо учитывать менталитет с целью корректного введения новаций. Дается обоснование авторской позиции восприятия менталитета через призму системно-векторной психологии Юрия Бурлана.

Ключевые слова: менталитет; образование; российский менталитет; системновекторная психология Юрия Бурлана. 